\title{
European Parliament the Democratic Representative for the People of Europe
}

\section{Enertila Bekteshi}

\author{
The Institute for European Studies/TU \\ Psychologist/Tirana University Hospital Center \\ Email: benertila@hotmail.com
}

\section{Doi:10.5901/mjss.2017.v8n1p340}

\section{Abstract}

The history of the European Parliament can be seen as part of the development process toward a federal parliament supported by some researchers, but however another viewpoint of EU nature, as an international organization would be influenced from the European Parliament's viewpoint as well. It has been admitted that formal upcoming changes have turned it into a codecision-maker with the Council of Ministers. There isn't any other organization, where the member countries should share the decision-making process with the institutions which have been selected directly. In fact, during the creation of the united Europe, the power of the European Parliament have continuously increased trying to reduce the "democratic deficit" for which the Community is accused. Also the role of the EP role as an alternative point of access in the "policy-making'" process for interests that feel excluded from the domination of business interests could help in building a sense of European Identity among such groups in the longer term. The European Parliament appoints an Ombudsman, who may receive complaints from any citizen of the Union or from any other natural person or legal entity living or having his/her statutory residence/registered office in a member country. The cases handled by an Ombudsman are related to the bad administration of the institutions or community bodies' activities except the Court of Justice and the General Court in their court functions. The Ombudsman works in full competence and does not accept or require directives from any other organization. During his assignment must not perform any other professional activity for free or against payment. He is appointed by the European Parliament with the same duration of his legislature having a renewable mandate. In the DPB are provided also the Ombudsman's norms that might have in the cases of bad administration in conjunction with the activity of institutions in this sector. Thus, it will be solved the problem of accusation for lacking of transparency addressed to this sector.

Keywords: development process, democratic deficit, alternative access, bad administration.

The idea that the MPs of the member countries should be join the other new institutions that were established after 1951 has been also embraced by the federalist MP of the National French Assembly, (Assemblee Nationale) Andre Philip. Andre Philip proposed that the MPs should have been aware on the actions and decisions taken by the Community which became liable for governing important economic sectors for the democratic countries like coal and steel (article 13 of the treaty), ${ }^{1}$ General Assembly established with KEQQ was comprised of representatives of member countries' parliaments. They were elected by general voting for five years and enjoyed the following competences: 1) power of political control by analyzing the annual report submitted by the High Authority, 2) the right of questioning the High Authority on the method and reasoning used for the decisions taken, 3) the right to the motion of no confidence toward the High Authority which approval would be replaceable immediately upon its decision, 4) the right of consulting functions for the Commission and the Council.

The treaties establishing the European Economic Community and the EAEC (Euratom) signed in 1957 in Rome (effective in 1958), the Parliamentary Assembly inherited the main power; the executive control of the Community. It was still foreseen an institution from the treaty and election of members to be made by general voting. The EEC Treaty defined as member of the Parliamentary Assembly "representative of countries being part of the Communities" (article 137, direct election procedure from citizens). Indeed, this election method has failed, but article 138/1 of the EEC Treaty (same with other treaties) states that the Assembly is comprised of MPs from national parliaments.

This article was introduced by the European Community Studies Association (ECSA) in an Austrian conference on the "Democracy in Europe and European Parliament", held in Vienna from 19-21 May, 1999 and appeared at the Union no. 1, 1999, and as part of the series of European Essays published by Federal Trust, London; are appointed under the provided by each member country. The election methods were not the same but varied according to the terms of each member country. This enabled the countries to disrespect the criteria for proportionality of the political forces represented in the national parliaments thus causing an unreal representation of the political forces in the European Parliament. ${ }^{2}$ In fact, such

\footnotetext{
1 www.fedtrust.co.uk.

${ }^{2}$ E.g Italy starting from 1969 was represented in the Assembly by members of all parliamentary political groups, while France excluded from the representation in the European Parliament some forces which were not part of the governmental majority.
} 
inadequacy drew the attention of all writers of the treaty to whom this election system was temporary. Article $138 / 3$ granted to the Assembly the role to proceed further for the establishment of an organization having final character "created to comprise one of the elements of a future federal or confederal structure based on the principle of the separation of powers and that would require in particular a representative authority of two houses"3. The Assembly should have made possible the general direct election based on a uniform procedure for all the member countries, and the Council, upon an unanimous decision, would establish provisions for which would recommend the enforcement from member countries in conformity with their constitutional norms. ${ }^{4}$ The Parliamentary Assembly had also the right to investigate the activities of the Council of Commission and gather information. By the resolution on 20 March 1958 the Parliamentary Assembly, adopt by itself the name "European Parliamentary Assembly", while on 30 March 1962 changed name into the "European Parliament", to emphasize the role that would play in the gradually developing community. The European Economic Community gave quickly its fruits and the member countries aimed to strengthen not only the economic cooperation among them; following such initiative on 19 October 1961 the Fouchet Committee was established 5 . The French government submitted a Treaty Project by which was aimed the political union of 6 member countries. The Assembly was imposed to not execute the 'censure vote' for the executives provided by the Treaty of Rome, but rather granting special competences and giving rights to make questions and recommendations to the Council. ${ }^{6}$ The first Fouchet Plan was not approved and in 1962, de Gaulle presented his plan for the future of Europe in the meeting of the ministers of foreign affairs in 17 April 1962, known as the "Second Fouchet Plan". This plan was some steps back in the lifecycle of the Community and diminished the rights of the Parliamentary Assembly and independent secretariat. Instead of it was foreseen a commission formed by diplomats supporting the Council. ${ }^{7}$ The ECC Treaty had decided to ratify the decisions on the financial resources of the Community by the member countries of the Community. The conflict between this principle and perseverance of the President de Gaulle on the national sovereignty resulted in the crisis of the Community of 1965-1966. On February 1965, the Second Chamber of the Dutch Parliament has decided that the Assembly should have authority on the public expenses of the Community. The principle that public expenses should be subject of the parliamentary control originates from the history of the Dutch political institutions and of course from the parliamentary democracy. The Netherlands admits that the European expenses cannot be controlled accurately from 6 separated parliaments and thus they should be controlled from the Assembly of the Community. In the Hague in 1969, upon French proposal, was held the a conference with the participation of the head of countries or government and ministers of foreign affairs. ${ }^{8}$ (de Gaulle was not anymore at the head of France, instead of him was the President Pompidou). The decisions taken in the conference started to be enforced and this ended up upon the approval of the Luxembourg Treaty which amended some articles of the ECC Treaty and through the Dutch proposal, the European Parliament gain authority over the community's budget which have been empowered even more after the amendment made with the Treaty of 1975. The parliament shares almost equal power with the Council on the budget expenses but with one major exception, disapproval from the French government which expressed its dissatisfaction on the amendments to the treaties giving less power to the Parliament on the agricultural expenses, which are equal to over two thirds of the total and have special importance for France.

The Luxembourg Treaty entitled the Parliament to express on the "non-compulsory expenditures". For compulsory expenditures, the Parliament could propose amendments considered accepted if the Council did not contested them with qualified majority. By the mid-70s, the Council did not agree on the direct election of the European Parliament. Even in this case, France was in opposition with the countries supporting such thesis. However, after the appointment of the President Valery Giscard D'Estaing, which coincided with the upcoming French presidency; the official France wanted to undertake European initiatives. Therefore, after the consulting with Monnet, Zhiskar D'Estenj, decided to bring two new idea for the scheme of the European Communities: 1. the transformation of ad hoc summits of the presidents of countries and heads of member government in the European Council and 2. The resolution of direct elections for the European Parliament. ${ }^{9}$ The initiative of direct elections was supported by many political forces of 6 member countries. The decision for running such initiative was taken in Rome in December 1975 from the European Council during the Italian presidency. ${ }^{10}$ The perspective of elections challenged the political parties to be assorted based on their programs and ideas at European level. In April 1974

\footnotetext{
${ }^{3}$ Fausto Pocar, The right of the European Communities, p. 19.

4 ibidem, Fausto Pocar p. 85.

${ }^{5}$ French diplomat. (Christian Fouchet)

${ }^{6}$ Paskal Milo. European Union p. 63.

${ }^{7}$ European Union. Paskal Milo (reference) Marie Therese Bitsch, p.194 64.

${ }^{8}$ Paskal Milo. European Union p. 91.

9 J. Monnet, Memoirs (London: William Collins Sons \& Co., 1979) p.p. 513.

${ }^{10}$ L. V. Majocchi and F. Rossolillo, R Parlamento europeo (European Parliament): Historical significance of an electioni:Guide editor, 1979) p.p. 101-4.
} 
was formed the union of the socialist parties of the European Community; in spring of 1976 was established the federation of the liberal parties and the European People's Party grouping the demochristians parties. The European People's gained clear characteristics of a real transnational party. ${ }^{11}$ The first direct ${ }^{12}$ parliamentary elections were held in 1979 . The direct voting by the citizens for the parliamentarians that would represent the future Europe's institutions increased the impact of the European Parliament. The other result of these elections was the granting of good faith to the Parliament to accept the initiative of Spineli ${ }^{13}$ on the draft of EU Treaty of federalist features, which was approved by considerable majority in February 1984. In fact, it was one of the two resources which lead to the negotiation of the Single European Act. Since then, the Parliament became the real institution, a representative of the Community's people and this election's method favorited the most the community policies. Obviously, this achievement continues also today but what changes from one member country to another is the election method of the European parliamentarians. There isn't any unified "European" election method for the parliamentarians. ${ }^{14}$ The elected parliamentarians are independent and cannot accept any mandatory mandate or instruction.

The name European Parliament (EP) was officially used in the Single European Act signed in 17 February in Luxembourg and in 28 February 1986 in Hague and entered into force in 1 July 1987. During the first half of 1984, France owned the upcoming presidency of the Community. After the Parliament voted the draft of EU Treaty, Spineli along with the European Parliament President, during a visit to the France's President François Mitterrand in 1984, gave him a copy of the draft (symbolically). In his speech to the European Parliament, the President Mitterrand expressed his support for the draft Treaty ${ }^{15}$, as well as in the next meetings of the European Council initiated by Dooge Committee (in the name of the Irish Leader) in the role of the personal representatives of the heads of countries and governments to submit concrete proposals for the institutional reforms in the upcoming meetings of the European Council. In January 1985, Jacques Delors, in his first declaration as the President of the European Commission, he said that he participated in some meetings in all capitals of the member countries of the Communities in order that the governments could accept the program of a single market, the common currency and the institutional reforms and admitted that the program of a single market was unanimously accepted. ${ }^{16}$ SEA presented a modification package of the establishing treaties of Rome and Paris, among which are: a) the official use of the term European Parliament although when related to early competences it couldn't be understood a bona fide parliament; b) transformation of EP into a political and legal actor much more important for the European integration between the establishment of 'the procedure of cooperation' and 'the procedure of consent'. The Parliament would give its consent for the agreements of association and membership, ${ }^{17}$ but of course the empowerment of the European Parliament's role as the main institution, the direct representative of the member countries' people has been considered in continuity and apparently has found the consensus in the solemn declaration of Stuttgart over EU. The Maastricht Treaty has modified the institutional equilibrium in favor of the European Parliament by expanding the a) power of political control of the Parliament toward the Commission $\left.{ }^{18}, b\right)$ procedure of cooperation and consent with the Commission for the decision that would have been undertaken, $\mathrm{c}$ ) set out the procedure of codetermination which places the Parliament in the same plan with the Council. The Commission's proposal should be transmitted the same way as in the Council and EP. This procedure comprises $80 \%$ of normative procedures of EC, d) necessity of taking EP's opinion on the treaties and international agreement signed with the third countries. EP's opinion should be in line with the Commission's opinion; otherwise the Parliament may impede the case. Whereas the Amsterdam Treaty signed in 2 October 1997 gave special attention to the treatment of the Union's institutions. For EP, the Amsterdam Treaty set out a number not exceeding 700 members with a right of a 5-year mandate. The changes provided in the treaty demanded the strengthening of the democratic grounds and expansion of EU responsibilities, beyond the achievements of SEA and EUT. ${ }^{19}$ The European Parliament gained wider competences in:

- establishing regulations for its members by taking firstly the Commission's opinion and unanimous approval of

\footnotetext{
11 Paskal Milo. European Union p. 123

12 European people vote themselves for their MPs that will represent them in the EP.

${ }^{13}$ Altiero Spineli, representative of the federalist method for establishement of Europe.

14 Some countries have the proportional election method, and others the majority election. Not only the election method but also the European MPs salaries vary from one member country to another. They are paid with the salaries of the national $M P$-s, although they are different in each of the member countries. The Italian MPs are paid the most.

15 Debates of the European Parliament, 24 May 1984.

16J. Delors, "Introduction of the New Commission", Debates of the European Parliament 1984-1985,report of proceedings from 1418 January 1985, Annex to OjfidalJoumal of the European Communities 2-1985, p.p. 3-11.

17 unw.europarl.eu.int

${ }^{18}$ Rights of European Communities. Iva Zajmi p. 84.

${ }^{19}$ European Union.Paskal Milo p. 217.
} 
the Council;

- appointing the Commission's President. The Commission's President would have been elected from the Parliament (ECT article 214);

- enjoying the right to be informed;

- giving the consent of the defining the European Commission; the Commission's President and in second phase, the entire Commission should have been approved by EP by voting, separately (ECT article 214, former article 158). The Parliament may follow a procedure of investigative control similar to "hearings" of the U.S. Senate in the case assignments (ECT article 214). ${ }^{20}$

- enjoying the right to submit a proposal on EP election through general direct election under a uniform procedure (ECT article 190.4);

- enjoying the right to ask from the Commission to submit legislative proposals (ECT article 192);

- enjoying the right in the co-decision procedure which replaces the cooperation procedure, almost in the all areas this procedure was included as well as in important political areas. This procedure allows EP to cancel or postpone the project legislation or propose amendment to it, passing it to a common committee EP-Council, known as the Conciliation Committee. In case the Council disputes the amendment proposed by EP, the Council and the Parliament should work in the Conciliation Committee to come out with a new project for the legislation. The new project should have the approval of the parties. The Treaty of Nice in 2001, provided the reforms in the European Parliament in two directions: a) Quantitative reform which should be made in light of the membership in the European Union of the other countries of Europe and the great increase of the number of the European Parliament ${ }^{20}$. b) Qualitative reform, by which is intensified the weight and role of such important mechanism. ${ }^{21}$ For the population from 25 million to 60 million will be calculated plus one MP for 2 million people. According to this formula, the 732 countries of the European Parliament for the EU members and candidates will be divided as follows; (Minimum of countries for each state will be 6 MPs. For a population from 1 million to 25 million will be calculated plus I (one) MP every 500 thousand habitants. Regarding the number, it was agreed that starting from the elections of June 2004 a new formula will be in place for dividing the electoral zones which number of the member countries 'people is fundamental. ${ }^{22} \mathrm{Also}$, the Treaty of Nice gives to EP a number of participation rights in those political areas where the Community's institutions do not have any general obligation to be advised with EP, but however can be advised. In case EP proposes changes for a certain project and the changes are supported by the Commission, the Council may approve them by qualified majority voting system or add the changes through unanimous voting. The rights defined in the treaty and the Parliament Regulation entitle the parliamentary committees to question the candidates. The European Parliament develops its work in particular parliamentary committees. (see table 3.5). Also, the Parliament should be consulted before the assignments in the Executive Board of the European Court of Justice and Court of Accounts (or Auditors). Of course, the protagonists of the debates in EP are the political groups. We currently see the concentration of the political forces in the European Parliament. (see figure 3.3) (table. 3. 6) Separation of countries in the European Parliament between the member countries:

\begin{tabular}{llll}
\hline 1. Belgium & 22 countries & 13. Austria & 17 countries \\
2. Denmark & 13 countries & 14. Portugal & 22 countries e \\
3. Spain & 50 countries & 15. England & 72 countries \\
4. Franc & 78 countries & 16. Hungary & 20 countries \\
5. Luxembourg & 6 countries & 17. Czech Republic & 20 countries \\
6. Netherlands & 25 countries & 18. Lithuania & 12 countries \\
7. Finland & 13 countries & 19. Poland & 50 countries \\
8. Sweden & 18 countries & 20. Sllovakia & 13 countries \\
9. Germany & 99 countries & 21. Cyprus & 6 countries \\
IO.Greece & 22 countries & 22. Estonia & 6 countries \\
II. Irland & 12 countries & 23. Letonia & 8 countries \\
12. 1 taliy & 78 countries & 24. Malta & 6 countries \\
& & 25. Slovenia & 7 countries
\end{tabular}

20 Institutional Reforms Manzella p.4 www.reforme.net

${ }^{21}$ Xhezair Zaganjori.Institutional Reforms of the European Union, p. 23.

22 Xhezair Zaganjori. Institutional Reforms of EU, p. 22. 
The European Parliament strengthened the competences even in the decision-making process for important problems together with the Council. Actually, it is a co-legislator with the Council but it isn't exactly a legislative body; co-approver of the budget (together with the Council); executes control in the Commission's activity, may vote the motion of no confidence which obliges the Commission to withdraw; appoints the Ombudsman to receive complaints on the misadministration of the community. The European Parliament won the right to address to the European Court of Justice regarding different cases in conjunction with the:

- lack of competence,

- clarification of various procedural problems,

- $\quad$ breach of the treaty's norms or other defined norms, ${ }^{23}$

also

- when an international agreement is against to the treaty's norms,

- declare its attitude on matters of special importance in the area of fundamental right in case foir such matters has been invested and are expected declarations from the European Council, as well,

- increase the supervising role toward the parliamentary political parties. ${ }^{24}$

The Constitutional Treaty increases the number of the parliamentarians in 750 countries under the principle, "degressive proportion", with min. 6, max. 96. Exact number of every country will be set out before the elections in $2009 .{ }^{25} \mathrm{EP}$ gains also wider powers especially in the legislative cases including the budgetary process. The mechanism of co-determination which places EP and the Council of Ministers in the same plan, lies in all the sectors, with few exceptions. The EP's competences remain limited in some strategic sectors of the national sovereignty starting from CFSP. ${ }^{26}$

\section{Voting Procedure}

The EEC Treaty and EU Treaty provide 3 different methods for the Parliament regarding the majority rule; a. majority with the two thirds of members; or $3 / 5$ of members; $b$. absolute majority of representatives and $c$. a combination of two majorities. ${ }^{27}$ As a rule, however, the resolutions, attitudes and motions are approved through a simple majority of votes. The changes within the context of the cooperation procedure, co-decision procedure and the motion within the context of the consent procedure are approved through the absolute majority of the members. The absolute majority is required even when are submitted changes for the procedure. In case of important decisions (e.g. a motion of no confidence for the Commission or decisions on the budget). Other important motions, censure toward the Commission or budgetary motions should be approved by quorum. All parliamentary non internal decisions are taken in plenary sessions with several parliamentary bodies.

\section{Competences and Rights of the European Parliament and Participation in the Preparation of the Legislation}

EP has the right of consultation, the right of investigating the activities of the other institutions, the right of codecision in the legislation and the right of assignment and confirmation of the holders of job positions. Also, the EP may question the Commission ${ }^{28}$, participate in the areas not defined by the treaties (non-disclosure information for trade negotiation and agreement of association); questions the Presidency on the matters related to CFSP, JHA and formal preparation of the legislation; approves or refutes the assignments for the new European Commission. ${ }^{29} \mathrm{EP}$ participates in the preparation of the legislation through below methods:

- facultative consultation from the Council of Ministers or the Commission;

- compulsory consultation from the Council;

- cooperation procedure (ECT article 252, former article 189c);

- co-decision procedure (ECT article 251, former article 189b);

- the right of co-decision on the budget (ECT article 272, former article 203);

- the right to approve or refute the legislative acts and to confirm or reject the Treaty of Accession, the agreements of associations and other important treaties.

The Rights to Supervise the Activities of the Other Institutions

At the beginning, the ECT granted rights to EP to supervise the activities of the Commission. Based on the

${ }^{23}$ EUT article 230.

${ }^{24}$ Alessanda Zanobetti. Institutions and Authorities of EU. Lectures, p. 7.

${ }^{25}$ Summary of the constitution adopted by the European Council in Brussels on 17/ 18 June 2004.

${ }^{26}$ www, riforme.net (29.9.2004)

27 Europe of Communities. French documentation. Paris 1992. p. 33

${ }^{28}$ ECT article 197, former article 140. Summary of treaties.

${ }^{29}$ ECT article 214, former article 158. Summary of treaties. 
Maastricht Treaty, EP monitors the activities of all the institutions of the European Union and European Council regarding the Common Foreign and Security Policy (CFSP) and Justice and Home Affairs (JHA). By the end of each financial year, all the EU institutions are required to calculate their finances. Based on the annual report prepared by the Court of Auditors, the EP Committee for the Budgetary Control decides whether it approves or not the way the Commission has managed the finances during the previous financial year (known as 'discharge' from liability). In case EP ${ }^{30}$ refutes to approve the financial matters of the Commission, then we can say that we are in a midst of a serious situation that may lead to the resignation of the entire Commission. The mos powerful instrument that EP may use to supervise the Commission is taking actions to censure it. Such action requires the support of the two thirds of all members.

The Relationship between EP and the Parliaments of the Member Countries

Prior to the direct elections in 1979, the MPs of EP were MPs of the national parliaments and had a dual mandate. From 1979 this dual mandate is not mandatory, and in fact some member countries prohibited the dual mandates. This has diminished considerably the relations between EP and the national parliaments. However, the national parliaments control how the EC law is enforced in their countries and continue to play an important role in case of amendments to the treaties. At the beginning of $90 \mathrm{~s}$, all the national parliaments had parliamentary authorities responsible for the EU matters, in which is noticed their involvement in the European policies of their respective governments. Therefore, EO and the national parliaments of the EU member countries have built several forms of cooperation to execute their rights vis-a-vis to executive. The earliest form was developed through the Conferences of the Presidents and Heads of Parliaments, the first of which gathered in January 1963. The Amsterdam Treaty provided either the rights of the national parliaments to analyze the activities of their governments or the relations between EP and national parliaments.

Below diagram summarizes the most important information mentioned above (figure 3.3, before the Treaty of Nice) European Parliament

\begin{tabular}{|c|c|c|c|}
\hline Inclusion & $\begin{array}{l}\text { Competences } \\
\text { (duties/td rights); }\end{array}$ & Working methods: & Inter-parliamentary Relationships \\
\hline $\begin{array}{l}626 \text { elected members, the Strasbourg } \\
\text { meeting. } \\
1 \text { president, } 14 \text { vice-president and five } \\
\text { quaestors elected for a term of } 2\end{array}$ & $\begin{array}{l}\text { - } \text { counseling } \\
\text { - } \text { participation } \\
\text { - } \text { supervision } \\
\text { - } \text { appointments }\end{array}$ & $\begin{array}{l}\text { These are defined in the Rules of } \\
\text { Procedure. Best part of work is } \\
\text { done in committees (17) }\end{array}$ & $\begin{array}{l}\text { - Cooperation with national parliaments } \\
\text { - association agreements (eg the Europe } \\
\text { Agreements with Eastern European } \\
\text { countries) }\end{array}$ \\
\hline
\end{tabular}

Relationships of the European Parliament with the Commission

The role of the European Parliament in the administrative norms has increased. Following the voting reform we see a riequilibration of the relation Parliament - Council even in this area of the norms. The groups of parties and parliamentary committees are gathered monthly before and when required during the plenary sessions. In case EP proposes amendments of common position, the next step is for the Commission that decides within month unless approves such amendments. If yes, the amendment of proposal would return to the Council of Ministers which may only reamend it unless votes unanimously. This gives to the Commission the discretion to the process. After this process, the Council has the final veto, at least until the European Parliament refutes the common position and the Council cannot achieve unanimity. In such case, the European Parliament may block the legislation. In October 2004, the Euro Parliament wins for the first time over the Council of Ministers of EU by putting at risk the voting process of the new European Commission due to the block of the Italian minister Rocco Butiglione's assignment as commissioner for Justice's matters. The President of the Commission, the former Belgium Prime Minister Jose Manuel Barroso, waived to lead the 25 commissioners in the voting process of the European Parliament. Such decision of Barosso was taken since the Commission did not have the necessary majority to vote in EP. His waiver only few days before the voting process in the Euro Parliament us the first time happening in the European Union and demonstrates that the EP role has become very important that can approve or refute the European commissioners and censure collectively the Commission. ${ }^{31}$

\section{Conclusion}

The story of the European Parliament may be seen as part of the development process toward a federalist parliament supported by some researches, but another viewpoint of EU nature as an international organization would be affected even from the EP's viewpoint. It has been admitted that further changes in the formal role has made it a co-decision

\footnotetext{
30 Corriere della Sera, Thursday 28, October 2004.

${ }^{31}$ EUT article 195, former article $138 \mathrm{e}$
} 
maker with the Council of Ministers. There isn't any other organization where the member countries should divide the decision-making process with the institutions elected directly. In fact, during the creation of the united Europe, the powers of the European Parliament have increased continuously as an effort to reduce the "democratic deficit" for which the Community is accused. The role of EP as an alternative access in the "policy-making" process for interests that feel excluded from the domination of the business interests, helps in the construction of a new sense of European identity among such long term groups.

Ombudsman

The European Parliament appoints an Ombudsman who receives complaints from any citizen of the Union or from any other natural person or legal entity living or has his/her statutory residence in a member country. ${ }^{33}$ The cases handled by the Ombudsman are related to the misadministration of the activity of the institutions or community authorities except the ECJ and Court of First Instance in the execution of their court functions. The Ombudsman executes his functions in full competence and does not accept or requires directives from any authority. During his duty, he shouldn't execute any other professional activity for free or against payment. He is also appointed by the EP with the same term of his legislature of renewable mandate. In the DPB are provided as well the Ombudsman's norms that may use in the cases of misadministration related to the activity of the institutions in this sector. Therefore, it is thought to be solved the problem for accuses on the lack of transparency addressed to this sector.

\section{Notes}

"Today EU is accused for "democratic deficit" i.e. many decisions are taken from the governments of the countries or their representatives; to avoid this phenomenon, a long rambling has occurred to add the power to the EP, especially related to the community legislation" (EU institutions and authorities, Allessandra Zanobetti).

From July 1999, the Conference of Presidents, upon the support of $3 / 5$ of the its members had always the right to submit near the Parliament a motion for the substitution of the President, representation of a committee or any other holder of a position in the Parliament.

In the work with the Council, the Assembly acted as a budgetary authority for the three European communities. It had also the right to investigate the activities of the Council and Commission and gather information.

Despite the new name it gave, the Single European Act turned EP into a very important political and legal actor in the European integration through the establishment of the "cooperation procedure".

Romano Prodi in the European Parliament in 3 October 2000 was expressed that:

The European process may find the origin of its democratic vitality only by dual legitimacy; legitimacy of European people represented by you, members of the European Parliament and legitimacy of the member countries which is based on the democratic elections. The EP as an expression of expanded Europe with direct general elections, is a specific institution dedicated to represent the union of the European citizens; and it is from your approval of the Commission that the Commission has the resource of its legitimacy, and in particular the member countries represented in the Council. ${ }^{32}$.

\section{References}

John Peterson, Michael Shackleton. The institution of European Union

TBE article 195, former article $138 \mathrm{e}$

Corriere della Sera, Thursday 28, October 2004,

TKE article 197, former article 140. Summary of treaties.

TKE article 214, former article 158. Summary of treaties.

TBE article 230.

Alessanda Zanobetti. Institutions and Authorities of EU. Lectures.

Summary of the constitution adopted by the European Council in Brussels on 17/ 18 June 2004.

www, riforme.net (29.9.2004)

Europe of Communities. French documentation. Paris 1992.

www.fedtrust.co.uk.

Paskal Milo. European Union.

J. Monnet, Memoirs (London: William Collins Sons \& Co., 1979).

L. V. Majocchi and F. Rossolillo, R European Parliament: Historical significance of an election (Napoli: Guide editor, 1979).

Riforme institucionali Manzella p.4 www.reforme.net

Xhezair Zaganjori. Institutional Reforms of the European Union.

Xhezair Zaganjori Institutional Reforms of EU.

32 John Peterson, Michael Shackleton. The institution of European Union pp. 112) 